\title{
PENINGKATAN HASIL BELAJAR IPA TENTANG USAHA PELESTARIAN \\ LINGKUNGAN MELALUI METODE CONTEXTUAL TEACHING AND LEARNING PADA SISWA KELAS V SEKOLAH DASAR HILIR KABUPATEN TANA TIDUNG
}

\author{
Puji Lestari
}

\author{
Guru Sekolah Dasar 001 Sesayap \\ pujilestari@gmail.com
}

\begin{abstract}
The purpose of this study was to determine how the application of methods Contextual Teaching and Learning (CTL), to improve learning outcomes subjects of Natural Sciences of Conservation Effort Lingkungan.Penelitian held in SDN 001 Sesayap Lower Tana Tidung, with research subjects fifth grade students who amounted to 30 people. This research is an action using a model Kemmis and McTaggart, conducted in two cycles. Each cycle consists of planning, implementing action, observation, and reflection action. The results showed an increase in student learning outcomes in subjects of Natural Sciences, in particular concerning environmental conservation efforts, by applying the method of Contextual Teaching and Learning (CTL). This is evidenced by the value of the test results of students in the first cycle that $70 \%$ of students who completed, increased in the second cycle to $100 \%$ of students who pass. Activities of teachers and students according to the steps of this method reach $100 \%$ (mastery learning) at the end of the second cycle. The conclusion of this study indicate that the application of the method of Contextual Teaching and Learning (CTL), enables students to improve learning outcomes Natural Sciences and can develop creativity and can cooperate well.
\end{abstract}

Keywords: Methods Contextual Teaching and Learning (CTL), Learning Outcomes IPA, Enterprises Environmental Conservation, Action Research.

Abstrak: Tujuan penelitian ini adalah untuk mengetahui cara penerapan metode Contextual Teaching and Learning (CTL), untuk meningkatkan hasil belajar mata pelajaran IPA tentang Usaha Pelestarian Lingkungan.Penelitian dilaksanakan di SDN 001 Sesayap Hilir Tana Tidung, dengan subjek penelitian siswa kelas V yang berjumlah 30 orang. Penelitian ini merupakan penelitian tindakan dengan menggunakan model Kemmis dan McTaggart, dilakukan dalam dua siklus. Setiap siklus terdiri dari tahap perencanaan, implementasi tindakan, pengamatan, dan refleksi tindakan. Hasil penelitian menunjukkan adanya peningkatan hasil belajar siswa pada mata pelajaran IPA, khususnya tentang usaha pelestarian lingkungan, dengan menerapkan metode Contextual Teaching and Learning (CTL). Hal ini dibuktikan dengan nilai tes hasil belajar siswa pada siklus I yaitu 70\% siswa yang tuntas, meningkat pada siklus II mencapai $100 \%$ siswa yang tuntas. Aktivitas guru dan siswa sesuai langkah-langkah metode ini mencapai $100 \%$ (mastery learning) pada akhir siklus II. Kesimpulan dari penelitian ini menunjukkan bahwa penerapan metode Contextual Teaching and Learning (CTL), membuat siswa dapat meningkatkan hasil belajar IPA serta dapat mengembangkan kreativitas dan dapat bekerjasama dengan baik.

Kata kunci: Metode Contextual Teaching and Learning (CTL), Hasil Belajar IPA, Usaha Pelestarian Lingkungan, Penelitian Tindakan. 
Di dalam kurikulum telah ditegaskan bahwa pembelajaran Sains harus menekankan pada penguasaan kompetensi melalui serangkaian proses ilmiah. Proses pembelajaran sains yang diharapkan adalah yang dapat mengembangkan keyakinan terhadap kebesaran Tuhan Yang Maha Esa, pemahaman konsep, aplikasi konsep, sikap ilmiah siswa yang mendasarkan pada kegiatan IPA terhadap isu-isu yang berkembang di masyarakat, untuk memperoleh bekal pengetahuan konsep dan keterampilan sains sebagai dasar untuk melanjutkan pendidikan kejenjang yang lebih tinggi.

Standar Kompetensi dalam kurikulum pada Sekolah Dasar (SD) atau Madrasah Ibtidaiyah (MI) merupakan standar minimum yang secara nasional harus dicapai oleh siswa dan menjadi acuan dalam pengembangan kurikulum di setiap satuan pendidikan.Pencapaian Kompetensi Dasar didasarkan pada pemberdayaan siswa untuk membangun keterampilan, bekerja ilmiah, dan pengetahuan sendiri yang difasilitasi oleh guru. Untuk mencapai tujuan tersebut, diperlukan berbagai upaya sehingga proses dan hasil pembelajaran IPA sesuai dengan yang diharapkan.

Proses belajar dapat diartikan sebagai tahapan perubahan perilaku kognitif, afektif, psikomotorik yang terjadi dalam diri siswa. Suyono dan Hariyanto (2011) mengungkapkan ada empat pilar dalam belajar (four pillars of education/learning), yaitu: (1) belajar untuk mengetahui (learning to know), (2) belajar untuk bekerja (learning to $d o$ ), (3) belajar untuk hidup berdampingan dan berkembang bersama (learning to live together), dan (4) belajar untuk menjadi manusia seutuhnya (learning to be).

Hasil belajar siswa adalah hasil yang diperoleh dari evaluasi atau tes dan aspekaspek lainnya yang dikuantitatifkan yang tercermin dari nilai raport yang diberikan oleh guru pada siswa setiap akhir masa belajar semester. Sedangkan menurut Sudjana Hasil belajar adalah kemampuan-kemampuan yang dimilki siswa setelah ia menerima pengalaman belajarnya.

H.W. Flower yang dikutip oleh Ahmadi dan Supatmo (2000) menyatakan Ilmu Pengetahuan Alam (IPA) adalah ilmu yang sistematis dan dirumuskan, yang berhubungan dengan gejala-gejala kebendaan dan didasarkan terutama atas pengamatan dan induksi.

Selain dari hal tersebut di atas, Cains dan Evans dalam Syofyan (2012) juga mengungkapkan tentang hasil belajar IPA dari segi proses, produk dan sikap. Dari segi produk, IPA berisi kumpulan pengetahuan yang meliputi fakta, konsep, prinsip, hukum, dan teori yang merupakan hasil rekaan manusia dalam rangka memahami dan 
menjelaskan alam dengan berbagai fenomena yang terjadi di dalamnya.

Berdasarkan hal-hal yang tersebut di atas maka, Hasil Belajar IPA adalah skor yang didapat siswa setelah menjawab instrumen yag sengaja dibuat oleh peneliti untuk mengukur variabel hasil belajar IPA tentang usaha pelestarian lingkungan. Adapun indikator yang dipergunakan untuk menyusun instrumen hasil belajar IPA dalam penelitian ini adalah menyebutkan,menyimpulkan,mendemonstrasi kan, melaksanakan, dan membuat.Setelah mengaplikasikan indikator-indikator tersebut, siswa diharapkan akan mampu menerapkan dalam kehidupan mereka sehari-hari, sehingga siswa akan mampu menyelesaikan permasalahan yang dihadapinya dengan baik.

Usaha Pelestarian Lingkungan sangat erat kaitannya dengan pelajaran IPA. Pengertian hasil belajar IPA tentang Usaha Pelestarian Lingkungan adalah perubahan perilaku yang diperoleh oleh siswa setelah mengalami proses pembelajaran yang menyebabkan siswa memiliki kemampuan dalam memahami usaha pelestarian lingkungan, sehingga siswa akan mampu menerapkan usaha-usaha pelestarian lingkungan dalam kehidupan sehari-hari yang ditandai dengan kemampuan siswa sebagai berikut: 1) siswa dapat menyebutkan penyebab kerusakan lingkungan, akibat tidak menjaga kelestarian lingkungan, dan usahausaha pelestarian lingkungan, 2) siswa dapat mendemonstrasikan penjernihan air secara ssederhana, 3) siswa dapat membuat kerajinan tangan yang berasal dari bahan-bahan sampah. Kemudian kemampuan tersebut diukur melalui indikator keterampilan proses yaitu (1) mengamati (2) mengklasifikasikan (3) menginterpretasikan (4) meramalkan (4) merencanakan (6) menerapkan mengkomunikasikan.

Penelitian ini menggunakan metode Contextual Teaching and Learning (CTL). Hamdayama (2014) berpendapat Contextual Teaching and Learning adalah konsep belajar dimana guru menghadirkan dunia nyata ke dalam kelas dan mendorong siswa membuat hubungan antara pengetahuan yang dimilki dengan penerapan dalam kehidupan seharihari, siswa memperoleh pengetahuan dan keterampilan dalam konteks yang terbatas sedikit demi sedikit, dan dari proses merekonstruksi sendiri, sebagai bekal dalam memecahkan masalah kehidupannya sebagai anggota masyarakat. Berdasarkan pendapat tersebut CTL merupakan suatu rancangan pembelajaran yang disiapkan oleh guru yang mengaitkan dengan pengalaman-pengalaman nyata para siswa, kemudian para siswa menghubungkan pengalaman-pengalaman mereka tersebut dengan keadaan nyata siswa, sehingga siswa akan mampu merekonstruksi 
sendiri, pada akhirnya siswa akan mampu untuk memecahkan masalah yang dihadapinya.

Nurhadi yang dikutip oleh Rusman (2012) mengungkapkan Pembelajaran Contextual Teaching and Learning merupakan konsep belajar yang dapat membantu guru mengaitkan antara materi yang diajarkannya dengan situasi dunia nyata siswa dan mendorong siswa membuat hubungan antara pengetahuan yang dimilikinya dengan penerapannya dalam kehidupan mereka sebagai anggota keluarga dan masyarakat.

Sejalan dengan hal di atas, Ngalimun (2012) mengatakan pembelajaran Contextual Teaching and Learning adalah pembelajaran yang dimulai dengan sajian atau hanya tanya jawab lisan (ramah, terbuka, negosiasi) yang terkait dengan dunia nyata kehidupan siswa (daily life modeling), sehingga akan terasa manfaat dari materi yang akan disajikan, motivasi belajar muncul, dunia pikiran siswa menjadi konkret, dan suasana menjadi kondusif, nyaman dan menyenangkan. Sedangkan Johnson yang dikutip oleh Rusman (2012) mengatakan bahwa:

Contextual Teaching and Learning enables studenst to connect the content of academic subject with the immediate context of their daily lives to discover meaning. It enlarges their personal context furthermore, by providing students with fresh experience that stimulate the brain to make new connection and consecuently, to discover new meaning.

Senada dengan hal tersebut di atas, Sanjaya (2006) mengatakan contextual Teaching and Learning (CTL) adalah suatu strategi pembelajaran yang menekankan kepada proses keterlibatan siswa secara penuh untuk dapat menemukan materi yang dipelajari dan menghubungkannya dengan situasi kehidupan nyata sehingga mendorong siswa untuk dapat menerapkannya dalam kehidupan mereka

Berdasarkan penjelasan di atas, metode pembelajaran Contextual Teaching and Learnng materi pelajaran disajikan melalui konteks kehidupan siswa, sehingga pembelajaran akan lebih berarti dan menyenangkan. Siswa akan bekerja keras untuk mencapai tujuan pembelajaran, mereka menggunakan pengalaman dan pengetahuan sebelumnya untuk membangun pengetahuan baru. Selanjutnya siswa memanfaatkan kembali pengetahuan dan kemampuannya itu dalam berbagai konteks di luar sekolah untuk menyelesaikan masalah dunia nyata yang kompleks, baik secara mandiri maupun dengan berkelompok.

Pemaduan materi pelajaran dengan konteks keseharian siswa di dalam pembelajaran Contextual Teaching and Learning jugaakan menghasilkan dasar-dasar pengetahuan yang mendalam di mana siswa 
kaya akan pemahaman masalah dan cara untuk menyelesaikannya. Siswa mampu secara independen menggunakan pengetahuannya untuk menyelesaikan masalah-masalah baru yang belum pernah dihadapi, dan juga siswa memiliki tanggung jawab yang lebih terhadap pembelajaran seiring dengan peningkatan pengalaman dan pengetahuan mereka.

\section{METODE}

Tujuan penelitian ini adalah untuk meningkatkan kualitas pembelajaran di kelas, dan secara khusus bertujuan untuk mengetahui penerapan metode contextual teaching and learning dapat meningkatkan hasil belajar IPA pada siswa kelas V SDN 001 Sesayap Hilir Kabupaten Tana Tidung.

Penelitian ini merupakan Classroom Action Research atau penelitian tindakan kelas yang dilakukan dalam bentuk siklus. Rancangan tindakan penelitian yang digunakan dalam penelitian ini adalah model dari Kemmis dan Taggart berupa suatu siklus spiral. rancangan penelitian yang digunakan adalah suatu putaran kegiatan meliputi tahaptahap rancangan pada setiap putaran yaitu (1) perencanaan (planning); (2) tindakan (acting); (3) pengamatan (observing); (4) refleksi (reflecting) dan dilanjutkan lagi ke perencanaan kembali (replanning) sebagai dasar untuk strategi pemecahan masalah.
Hubungan antara keempat tahap dalam sistem ini dipandang sebagai satu siklus.

Penelitian ini dilaksanakan dalam dua siklus, masing-masing siklus 3 kali peretemuan, waktu setiap kali pertemuan $2 \mathrm{x}$ 35 menit, dan dilaksanakan sesuai dengan perubahan yang ingin dicapai. Teknik pengumpulan data dalam penelitian ini dibedakan atas dua jenis, yaitu untuk mengumpulkan data nilai tes digunakan lembar penilaian hasil belajar berupa tes obyektif, sedangkan untuk mengumpulkan data non tes dilakukan dengan cara (1) melalui observasi langsung dengan menggunakan lembar observasi aktivitas guru dan siswa, yang mana observasi langsung ini dilaksanakan sejak awal kegiatan pembelajaran sampai akhir pembelajaran; (2) catatan lapangan untuk mencatat setiap tindakan atau aktivitas guru dan siswa; (3) dokumentasi berupa rekaman atau foto-foto selama kegiatan pembelajaran berlangsung.

Berdasarkan pedoman pengumpulan data, maka kisi-kisi instrumen yang ditetapkan dalam penelitian ini, yaitu instrumen hasil belajar yang menggunakan data kuantitatif, sehingga data ini berupa angka yang diperoleh dari hasil pengukuran. Sedangkan data kualitatif berupa lembar observasi kegiatan guru dan siswa, akan diubah dalam bentuk data kuantitatif, untuk melihat persentase pencapaian tujuan 
pembelajaran, yaitu sampai mencapai kentutasan belajar 100\% (matery learning).

Tabel 1. Kisi-Kisi Instrumen Pilihan Ganda Hasil Belajar IPA Tentang Materi Usaha Pelestarian Lingkungan

\begin{tabular}{|c|c|c|c|}
\hline No & Indikator & Nomor Soal & Jumlah \\
\hline 1 & $\begin{array}{l}\text { Mengamati penyebab kerusakan lingkungan, } \\
\text { akibat tidak menjaga kelestarian lingkungan, dan } \\
\text { usaha-usaha pelestarian. }\end{array}$ & $5,13,17$ & 3 \\
\hline 2 & $\begin{array}{l}\text { Mengklasifikasikan penyebab kerusakan } \\
\text { lingkungan, akibat tidak menjaga kelestarian } \\
\text { lingkungan, dan usaha-usaha pelestarian. }\end{array}$ & $6,7,19$ & 3 \\
\hline 3 & $\begin{array}{l}\text { Menginterpretasikan penyebab kerusakan } \\
\text { lingkungan, akibat tidak menjaga kelestarian } \\
\text { lingkungan, dan usaha-usaha pelestarian. }\end{array}$ & 11,12 & 2 \\
\hline 4 & $\begin{array}{l}\text { Memprediksi penyebab kerusakan lingkungan, } \\
\text { akibat tidak menjaga kelestarian lingkungan, dan } \\
\text { usaha-usaha pelestarian. }\end{array}$ & $1,4,9$ & 3 \\
\hline 5 & $\begin{array}{l}\text { Merencanakan penyebab kerusakan lingkungan, } \\
\text { akibat tidak menjaga kelestarian lingkungan, dan } \\
\text { usaha-usaha pelestarian. }\end{array}$ & $16,18,20$ & 3 \\
\hline 6 & $\begin{array}{l}\text { Menerapkan penyebab kerusakan lingkungan, } \\
\text { akibat tidak menjaga kelestarian lingkungan, dan } \\
\text { usaha-usaha pelestarian. }\end{array}$ & 2,3 & 2 \\
\hline 7 & $\begin{array}{l}\text { Mengkomunikasikan penyebab kerusakan } \\
\text { lingkungan, akibat tidak menjaga kelestarian } \\
\text { lingkungan, dan usaha-usaha pelestarian. }\end{array}$ & $8,10,14,15$ & 4 \\
\hline & Total & & 20 \\
\hline
\end{tabular}

Table 2.Kisi-Kisi Instrumen Unjuk Kerja Hasil Belajar IPA Tentang Materi Usaha Pelestarian Lingkungan

\begin{tabular}{cccc}
\hline No & Indikator & Nomor Soal & Jumlah \\
\hline 1 & $\begin{array}{l}\text { Siswa mampu mendemonstrasikan penjernihan } \\
\text { air secara sederhana }\end{array}$ & $1-6$ & 6 \\
2 & $\begin{array}{l}\text { Siswa mampu membuat kerajinan tangan yang } \\
\text { berasal dari bahan-bahan sampah }\end{array}$ & $1-6$ & 6 \\
\hline & Total & 12 \\
\hline
\end{tabular}


Setelah melakukan analisis data, langkah selanjutnya adalah interpretasi hasil analisis yang dilakukan oleh peneliti dan observer. Hasil analisis disajikan dalam bentuk tampilan data berupa diagram batang. Berdasarkan diagram yang ditampilkan dapat dilihat hasil presentase penilaian dan peningkatan yang diperoleh dari setiap siklus. Apabila semua indikator keberhasilan yang ditetapkan dalam instrumen berhasil dicapai, maka dapat diinterpretasikan bahwa kualitas pembelajaran melalui metode Contextual Teaching and Learning berhasil ditingkatkan.

\section{HASIL}

Dalam penelitian ini jumlah siswa adalah 30 orang dengan jumlah butir soal tes pilihan ganda 20 butir. Aktivitas guru pada pertemuan 1 sebesar $75 \%$, peretemuan 2 sebesar $83 \%$, pertemuan 3 sebesar $88,90 \%$. Dengan demikian rata-rata persentase nilai aktivitas guru pada siklus I adalah sebesar $(75,00 \%+83,00 \%+88,90 \%)$ : $3=82,3 \%$. Persentase nilai aktivitas guru tersebut menunjukkan bahwa hasil yang dicapai belum memuaskan karena terdapat beberapa tindakan yang belum dilaksanakan oleh guru dalam pembelajaran dengan metode Contextual Teaching and Learning (CTL).Untuk melihat sejauh mana terjadinya peningkatan hasil belajar siswa pada mata pelajaran IPA tentang usaha pelestarian lingkungan. Setelah data nilai siswa pada siklus I diolah (dapat dilihat pada lampiran tes hasil belajar siklus I), maka daftar nilai siswa disajikan dalam tabel berikut:

Tabel 3. Daftar Nilai Hasil Belajar Siswa Pada Mata Pelajaran IPA Tentang Usaha Pelestarian Lingkungan (Siklus I)

\begin{tabular}{cccccc}
\hline No & Nama & Tes Unjuk Kerja & Tes Tertulis & $\begin{array}{c}\text { Nilai } \\
\text { Akhir }\end{array}$ & Keterangan \\
\hline 1 & AYN & 57 & 60 & 59 & Tdk Tuntas \\
2 & AKL & 73 & 80 & 77 & Tuntas \\
3 & ALA & 59 & 50 & 55 & Tdk Tuntas \\
4 & DND & 67 & 80 & 74 & Tuntas \\
5 & DFT & 69 & 80 & 75 & Tuntas \\
6 & FTR & 65 & 60 & 63 & Tdk Tuntas \\
7 & FAN & 75 & 75 & 75 & Tuntas \\
8 & FZL & 50 & 55 & 53 & Tdk Tuntas \\
9 & FZN & 73 & 85 & 79 & Tuntas \\
10 & FBI & 71 & 65 & 68 & Tuntas \\
\hline
\end{tabular}




\begin{tabular}{|c|c|c|c|c|c|}
\hline No & Nama & Tes Unjuk Kerja & Tes Tertulis & $\begin{array}{l}\text { Nilai } \\
\text { Akhir }\end{array}$ & Keterangan \\
\hline 11 & GLG & 69 & 85 & 77 & Tuntas \\
\hline 12 & GTA & 73 & 75 & 74 & Tuntas \\
\hline 13 & HLD & 69 & 75 & 72 & Tuntas \\
\hline 14 & IDY & 80 & 95 & 88 & Tuntas \\
\hline 15 & ISM & 80 & 90 & 85 & Tuntas \\
\hline 16 & JYN & 73 & 75 & 74 & Tuntas \\
\hline 17 & KSN & 58 & 50 & 54 & Tdk Tuntas \\
\hline 18 & MLA & 75 & 70 & 73 & Tuntas \\
\hline 19 & $\mathrm{LTF}$ & 79 & 80 & 80 & Tuntas \\
\hline 20 & NHT & 59 & 60 & 60 & Tdk Tuntas \\
\hline 21 & RSA & 69 & 65 & 67 & Tuntas \\
\hline 22 & $\mathrm{OKT}$ & 61 & 55 & 58 & Tdk Tuntas \\
\hline 23 & SPR & 69 & 70 & 70 & Tuntas \\
\hline 24 & SLS & 71 & 60 & 66 & Tuntas \\
\hline 25 & SMN & 73 & 90 & 82 & Tuntas \\
\hline 26 & SYH & 75 & 85 & 80 & Tuntas \\
\hline 27 & TFK & 79 & 95 & 87 & Tuntas \\
\hline 28 & TAR & 65 & 60 & 63 & Tdk Tuntas \\
\hline 29 & YSN & 56 & 50 & 53 & Tdk Tuntas \\
\hline 30 & YLN & 71 & 80 & 76 & Tuntas \\
\hline \multicolumn{3}{|c|}{ Nilai Rata-rata } & & 70,5 & \\
\hline
\end{tabular}

Selanjutnya dapat dideskripsikan bahwa nilai yang belum tuntas yaitu yang mendapat nilai kurang dari 65 sebanyak 9 siswa (30\%), sedangkan sebanyak 21 siswa (70\%) dikatakan sudah tuntas. Dengan demikian dapat disimpulkan bahwa ketuntasan hasil belajar pada siklus I mencapai 70\%, dengan jumlah siswa yang tuntas sebanyak 21 orang, hal ini dikatakan meningkat dibandingkan dengan hasil pada saat sebelum dilakukan tindakan pembelajaran dengan menggunakan metode Contextual Teaching and Learning. Dimana ketuntasan hasil belajar sebelum dilaksanakan tindakan dengan menggunakan metode Contextual Teaching and Learning yaitu hanya $43 \%$, dengan jumlah siswa yang tuntas 13 0rang. Hal tersebut sesuai dengan data hasil wawancara antara peneliti dengan guru kelas. Walaupun sudah menunjukkan peningkatan dengan nilai rata-rata 70,5 , tetapi pencapaian ini belum mencapai standar minimal yaitu $80 \%$ dari keseluruhan siswa yang mencapai KKM (65). Hal ini diperkuat dengan jumlah skor yang dicapai berdasarkan lembar observasi kegiatan guru dan siswa, ternyata belum mencapai maksimal seperti yang ditargetkan.

Berdasarkan hasil analisis siklus II, disimpulkan bahwa telah terjadi peningkatan yang signifikan untuk hasil belajar siswa mata pelajaran IPA tantang usaha pelestarian lingkungan melalui metode Contextual Teaching and Learning (CTL).Tindakan pembelajaran yang dilakukan telah tuntas 
mencapai 100\% (mastery learning), dimana kelemahan-kelemahan pada siklus I sudah teratasi.Pada siklus II ini persentase nilai aktivitas guru dan siswa pada tiap pertemuan semuanya telah mencapai $100 \%$.

Untuk memperoleh data hasil belajar IPA yang dicapai sebagai dampak dari pelaksanaan pembelajaran dengan metode Contextual Teaching and Learning peneliti melaksanakan evaluasi. Skor dan nilai hasil belajar siswa mata pelajaran IPA tentang usaha pelestarian lingkungan yang diperoleh berdasarkan tes sebagaimana tertera pada tabel berikut:

Tabel 4. Daftar Nilai Hasil Belajar Siswa Pada Mata Pelajaran IPA Tentang Usaha Pelestarian Lingkungan (Siklus II)

\begin{tabular}{cccccc}
\hline No & Nama & Tes Unjuk Kerja & Tes Tertulis & $\begin{array}{c}\text { Nilai } \\
\text { Akhir }\end{array}$ & Keterangan \\
\hline 1 & AYN & 77 & 70 & 74 & Tuntas \\
2 & AKL & 86 & 80 & 83 & Tuntas \\
3 & ALA & 77 & 80 & 79 & Tuntas \\
4 & DND & 82 & 80 & 81 & Tuntas \\
5 & DFT & 84 & 80 & 82 & Tuntas \\
6 & FTR & 86 & 70 & 78 & Tuntas \\
7 & FAN & 88 & 75 & 81 & Tuntas \\
8 & FZL & 84 & 70 & 77 & Tuntas \\
9 & FZN & 100 & 90 & 95 & Tuntas \\
10 & FBI & 94 & 80 & 87 & Tuntas \\
11 & GLG & 88 & 85 & 87 & Tuntas \\
12 & GTA & 90 & 80 & 85 & Tuntas \\
13 & HLD & 90 & 75 & 83 & Tuntas \\
14 & IDY & 92 & 100 & 96 & Tuntas \\
15 & ISM & 94 & 100 & 97 & Tuntas \\
16 & JYN & 92 & 75 & 84 & Tuntas \\
17 & KSN & 88 & 70 & 79 & Tuntas \\
18 & MLA & 92 & 70 & 81 & Tuntas \\
19 & LTF & 94 & 80 & 87 & Tuntas \\
20 & NHT & 82 & 70 & 76 & Tuntas \\
21 & RSA & 88 & 85 & 86 & Tuntas \\
22 & OKT & 82 & 70 & 76 & Tuntas \\
23 & SPR & 88 & 85 & 87 & Tuntas \\
24 & SLS & 90 & 75 & 82 & Tuntas \\
25 & SMN & 94 & 90 & 92 & Tuntas \\
26 & SYH & 92 & 85 & 89 & Tuntas \\
27 & TFK & 96 & 95 & 96 & Tuntas \\
28 & TAR & 83 & 85 & 84 & Tuntas \\
29 & YSN & 84 & 75 & 79 & Tuntas \\
30 & YLN & 88 & 80 & 84 & Tuntas \\
\hline & Nilai Rata-rata & & & 84,2 & \\
\hline & & & & & \\
\hline
\end{tabular}


Sesuai tabel 4, dapat dideskripsikan bahwa seluruh siswa kelas V sebanyak 30 siswa (100\%), dikategorikan sudah tuntas dan sudah menunjukkan peningkatan nilai rata-rata kelas yaitu 84,2. Dengan demikian pencapaian ini sudah mencapai standar minimal yaitu $80 \%$ dari keseluruhan siswa yang mencapai KKM 65.Hal ini diperkuat dengan data hasil observasi guru dan siswa yang telah mencapai 100\%.Oleh karena itu diputuskan tindakan tidak dilanjutkan ke siklus berikutnya.

\section{PEMBAHASAN}

Hasil penelitian yang diperoleh dalam penelitian ini menunjukkan hasil belajar pada siklus I mencapai 70\%, dengan jumlah siswa yang tuntas sebanyak 21 orang, hal ini dikatakan meningkat dibandingkan dengan hasil pada saat sebelum dilakukan tindakan pembelajaran dengan menggunakan metode Contextual Teaching and Learning. Dimana ketuntasan hasil belajar sebelum dilaksanakan tindakan dengan menggunakan metode Contextual Teaching and Learning yaitu hanya $43 \%$, dengan jumlah siswa yang tuntas 13 Orang.

Berdasarkan hasil analisis siklus II, disimpulkan bahwa telah terjadi peningkatan yang signifikan untuk hasil belajar siswa mata pelajaran IPA tantang usaha pelestarian lingkungan melalui metode Contextual Teaching and Learning (CTL).Tindakan pembelajaran yang dilakukan telah tuntas mencapai 100\% (mastery learning), dimana kelemahan-kelemahan pada siklus I sudah teratasi.Pada siklus II ini persentase nilai aktivitas guru dan siswa pada tiap pertemuan semuanya telah mencapai $100 \%$.

\section{SIMPULAN}

Proses pembelajaran Ilmu Pengetahuan Alam (IPA), khususnya materi Usaha Pelestarian Lingkungan dengan menggunakan metode Contextual Teaching and Learning, dapat meningkatkan efisensi pembelajaran. sesuai dengan hasil observasi aktifitas guru dan siswa, hasil catatan lapangan, hasil dokumentasi dan wawancara, maka langkah-langkah pembelajaran dengan menggunakan metode Contextual Teaching and Learning yang diterapkan, terus mengalami peningkatan, sehingga pada akhir siklus II proses pembelajaran telah berhasil dan tuntas yaitu telah mencapai 100\% (mastery learning). Sendana dengan penelitian ini, Satriani (2011) menunjukkan bahwa terjadi peningkatan hasil belajar menulis dengan penggunaan metode Contextual Teaching and Learning.

Proses pembelajaran dengan metode Contextual Teaching and Learning, khususnya materi Penjernihan air secara sederhana dan membuat kerajinan tangan berbahan dasar sampah, divariasikan dengan metode demonstrasi. Metode demonstrasi menjadi penunjang dalam proses pembelajaran, karena sangat membantu dalam merangsang keaktifan 
siswa ketika sedang berlangsungnya proses pembelajaran.

Keberhasilan pembelajaran Ilmu Pengetahuan Alam (IPA) di kelas V SDN 001 Sesayap Hilir, khususnya materi Usaha Pelestarian Lingkungan, ditandai dengan peningkatan pemahaman siswa dalam menjaga kelestarian lingkungan terutama dengan tidak membuang sampah disembarang tempat dan memanfaatkan sampah-sampah yang tidak beharga menjadi kerajinan tangan yang memiliki nilai guna. Dilihat dari hasil evaluasi siklus I dan II, kemampuan menjawab soal siswa terus mengalami peningkatan. Peningkatan yang signifikan terjadi pada siklus II dimana nilai rata-rata kelas telah melampaui KKM yaitu $84(\mathrm{KKM}=65)$, dengan jumlah siswa yang tuntas sebanyak 30 siswa (100\% dari jumlah keseluruhan siswa).

\section{DAFTAR RUJUKAN}

Ahmadi Abu dan Supatmo. 2000. Ilmu Alamiah Dasar. Jakarta: Rineka Cipta.

Hamdayama Jumanta. 2014. Model dan Metode Pembelajaran Kreatif dan Berkarakter.Bogor: Ghalia Indonesia.
Ngalimun. 2012. Strategi dan Model Pembelajaran. Yogyakarta: Aswaja Presindo.

Rusman. 2012. Model-model pembelajaran: Mengembangkan Profesionalisme Guru. Jakarta: PT RajaGrafindo persada.

Sanjaya Wina. 2006 Strategi Pembelajaran Berorientasi standar Proses Pendidikan. Jakarta: Kencana Prenadamedian group.

Satriani, Intan, dkk. 2011. Contextual Teaching And Learning Approach To Teaching Writing. Indonesian Journal of Applied Linguistics, Vol. 2 No. 1, July 2012, pp. $10-22$

Sudjana Nana. 2009. Penilaian Hasil Proses Belajar Mengajar.Bandung: Remaja Rosdakarya.

Suyono dan Hariyanto 2011. Belajar dan Pembelajaran. Bandung: Remaja Rosdakarya.

Syofyan Harlinda. 2012.Peningkatan Hasil Belajar IPA siswa kelas $V$ Melalui Metode Resitasi pada Pokok Bahasan Penyesuaian Makhluk Hidup Di SD Al Ahzar Syifa Budi Jakarta Selatan. Tesis, Universitas Negeri Jakarta 